一拡張にステロイドの局所，全身使用が用いら れる，皮膚形成手術後ステロイド軟膏塗布によ りケロイドの発生が予防される.

\section{5. 腫}

瘍

腫瘍の治療にやたらにステロイドを用いるべ きではないが，悪性リンパ腫には他の抗ガン 剂，照射療法と併用する。たとえばビンクリス チン，エンドキサン，6-MP とステロイドの併 用が VEMP 療法として用いられている. 延命
効果が期待できる.

$$
\text { 6. その他 }
$$

突発性難聴は症例により，ATP，血管拡張 戍，ビタミン $\mathrm{B}_{1}$ とステロイドを併用すること がある.

/原稿到着：炤和49年10月11日

別刷請求先 : 奥田 稔

函640 和歌山市七番丁 7

和歌山県立医科大学耳馩咽喉科学教室

\title{
小児耳鼻咽喉科疾患に対するステロイドの使用について
}

$$
\text { 末标势 }
$$

耳鼻咽喉科領域ではステロイドは主にその抗 炎症作用によって感染症に対して用いられる が，ステロイドの絶対適応となる疾患は少な く，かつ日常臨床でステロイドが単独に使用さ れることも一般的にはない，ステロイドには副 作用があるため安易に用いてはならず，とくに 連用は箱につつしむべきである，治療の核心は あくまで原疾患に対する根治療法にあり，ステ ロイドに主役的な意義はない，わたくしの小児 耳鼻咽堠科臨床の経験からもステロイドが治療 上決定的であったととはなく，それだけにステ ロイドの適応と効果を論ずるととは難しいとい える.しかし，一部の急性期の炎症性疾患は久 テロイドの併用によってよく治療しえたと考え

る.わたくしがステロイドを使用する場合はこ のような急性期の炎症性疾患が主たる対象であ り，以下に使用経験を述べる。

急性期の重篤な次济効象とするとと
が多いため，ステロイドとしては抗炎症作用の 強力な Dexamethasone (Decadron) をもつぱ ら用いた．使用方法は 2 ～才の幼児でいえば 普通はデカドロン $2 \mathrm{mg}$ ( 1 回量) を筋注した. 2 回以上続けて使用したてとは滅多にない。

1) Adenoiditis, Tonsillitis に対する使用 腺窩性扁桃炎の最盛期にステロイドを併用す れば効果的な場合がある. 幼児の扁桃炎のなか でもAdenoiditis を伴ない，かつ咽頭全体に浮 腫をきたすような高度の炎症はステロイド使用 の適応と考えるが，自験例は次のようである。

症例：3才，男子. 風邪にて 2 日前より発 熱，1日前より吸気性呼吸困難をきたして来院 した。栶頭視診により脉窩性扁桃炎と訬断し, 乙線検査（顔面側方撮影）で上咽頭は完全に閉 塞し高度の Adenoiditis が考えられた。ただち に入院させ，ビクシリン S $100 \mathrm{mg}$ とデカドロ ン $2 \mathrm{mg}$ を筋注し, ソリタ $\mathrm{T}_{3} 200 \mathrm{cc}$ を点滴,

The Uses of Steroids in Otolaryngology in Children.

Akira Kimura.

神戸大学医学部耳鼻财喉科学教室 
酸素テントを使用した。その結果，翌日には咽 頭の腫脹は著しく軽減し，喘鳴が消失した．入 院 2 日後には食欲が旺盛となり，症状はすっか り軽快した。本症例に対しては 1 力月後にアデ ノイド切除と扁切を実施した。

このように自験例では入院による安静と呼吸 管理が第一に効果をあげたと考えられるが，浮 腫を伴なうような高度の咽頭炎に対しては抗生 物質の投与下にステロイドが使用されると消炎 効果が大きいようである.

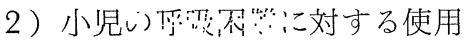

とくに矤頭，気管（支）の炎症性疾患による 呼吸困難に対して抗生物質，ネブライザ一の使 用下にステロイドを併用すれば有効である.

(1) 仮性クループ：この場合は抗生物質と併 用してぜひとも ステロイドを用いるべきであ る. 仮性クループの治療方針は声門下の腫脹を 早く消退させることと気道を乾燥させないとと の二つが柱であるが，呼吸困難が重篤であるだ けに来院した最初のてろの処置が大切である. 自験例の 2 症例（1.7才，2.1才の男子）ではい ずれも来院時に抗生物質とステロイド（デカド ロン $2 \sim 4 \mathrm{mg}$ 筋注）を使用し， $5 \%$ ブド一糖 の点滴, 酸素テント，ネブライザ一の使用で 1 〜2 日で軽快した。 2 例のうち 1 例はデカドロ ンを 1 回使用したのみであり，1例では翌日に 半量を追加した。

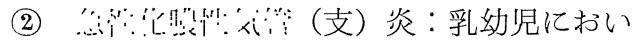
てとき亿重篤な急性気管（支）炎をみるが，気

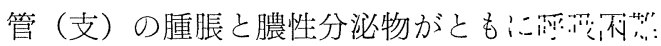
の原因となる.このような症例に対しては前述 の仮性クループと同様に治療するが，とくに祛 痰がはかどらず膿性分泌物による Obstruction がある場合，直達候頭鏡下に気管内挿管を行な い直接的な気管内吸引と生食水による気管 (支) 洗桬を実施し劇的な効果を収めることができ る。乙れは挿管と気道確保のために麻酔医の協 力下に行なうことがのぞましい.

(3) 気管(支)異物摘出後：全麻下の気管(支) 鏡検査によって異物を摘出したあと, 生食水に
仮性グループに対する処置（1〜3才を対象）

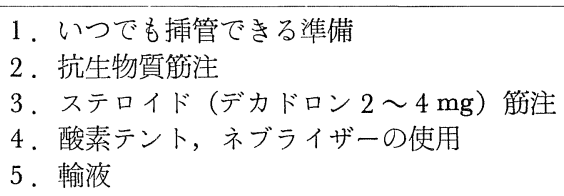

より気管 (支)洗滌をルーチンに行ない気管 (支) を清掃し，かつ抗生物質とステロイドを使用し ている. てのような処置により異物摘出 $1 \sim 2$ 日後には退院させるととが可能となった。

3 ）気道の検査・手術のあとでの使用 小児では值達喉頭鏡・気管（支）鏡検査後や 声帯ポリープ・小児結節の切除後, さらに喉頭 蓋チステの摘出後などに声門の術後性腫脹の予 防のためにステロイドを使用するのがよい。ま た，唇裂・口蓋裂，アデノイド・扁桃の手術後 にステロイドを使う必要はないが，しかし全麻 にさいして頻回に挿管をくり返したような場合 はやはり予防的にステロイドを使用しておく.

4 ）反復性中耳炎についての経験

急性中耳炎の手初めの治療法は鼓膜切開之抗 生物質投与である. 表の如く，初診時に鼓膜切 開をした 37例のうち 31例は 1 力月以内に治癒 し，30例は10日以内に治癒した，一方，6例の 反復性中耳炎のうち 4 例は Adenoiditis が背景 にあり, 最後はアデノイド切除を実施し改善し た。このうちの 2 例はとくに頻回に中耳炎を反

初診時に鼓膜切開をした37例の急性中耳炎の 予後（1970～72）－自験例-

\begin{tabular}{|c|c|c|c|c|c|c|}
\hline \multirow{3}{*}{$\begin{array}{l}\text { 初診時の } \\
\text { 鼓膜所見 }\end{array}$} & \multicolumn{2}{|r|}{ 治 } & \multicolumn{3}{|c|}{ 癒 } & \multirow{3}{*}{ 反復性中四炎 } \\
\hline & \multicolumn{4}{|c|}{$\begin{array}{l}\text { 治癒を確認した } \\
\text { とき }\end{array}$} & \multirow{2}{*}{ 計 } & \\
\hline & 2 星 & 5 星 & 10日 & $\begin{array}{l}1 \text { 力 } \\
\text { 月後 }\end{array}$ & & \\
\hline $\begin{array}{l}\text { 第 } 2 \text { 度 } \\
\text { 充 } 1 \text { 血 }\end{array}$ & 0 & 1 & 2 & 0 & 3 & 0 \\
\hline $\begin{array}{ll}\text { 第 } & \text { 度 } \\
\text { 充 } & \text { 血 }\end{array}$ & 9 & 9 & 5 & 1 & 24 & $\left.\begin{array}{c}4 \\
4 \text { 例之. } \\
\text { Adenoiditis }\end{array}\right)$ \\
\hline 笌 然 & 1 & 1 & 2 & 0 & 4 & $\left.\begin{array}{c}1 \\
1 \text { 例は乳様突起炎 } \\
1 \text { 例は Letterer- } \\
\text { Siwe Disease }\end{array}\right)$ \\
\hline 訫 & 10 & 11 & 9 & 1 & 31 & 6 \\
\hline
\end{tabular}


復したので, 鼓膜切開・抗生物質と併用してス テロイド（デカドロン $2 \mathrm{mg}$ 筋注）を 1 回のみ 用いた．たしかにそのときの中耳炎は早く消退 したが 1 〜 カ月後に再び反復し, 最終的には アデノイド切除により中耳炎の反復はやんだ.

この場合，ステロイドの効果は一時的なもので あり，4例の Adenoiditis 由来の反復性中耳炎 に対しては結局アデノイド切除が有効であっ た. ステロイドの作用は対症療法としての意味 しかなく，しかも一時的な効果しか期待できな いことを端的に示したものである。

5 ）ステロイド軟膏の使用

ステロイドの抗肉芽作用に注目して，わたく しは術後の創面の過剩な肉芽形成に対して少量 のステロイド軟高（テラコートリル軟膏）を使 用し，著効をえている，たとえば，鼓室形成術 後 2 〜 週して外耳道にまだ創面が存在する場
合，ステロイド軟膏を使用すれば創面は非常に 早く乾燥し，上皮化がおこる。創面が乾燥しは じめ，肉芽が減少しはじめればステロイド軟膏 の使用はうちきるとととする，ステロイド剤の 効果を最も顕著にあらわすのはてのようなステ ロイド軟膏の肉芽性創面に対する局所療法であ ろう。

以上，小児耳鼻咽喉科疾患に対するステロイ ド使用経験を述べたが，重篤な炎症性疾患であ るほどステロイド使用の適応となり, かつ効果 が大きいと考える。小児耳鼻咽瞙科臨床でステ ロイドを使うのは特別な場合であり，ルーチン に用いるような場合はない。

原稿到着：昭和49年10月 7 日

別刷請求先：木村 照

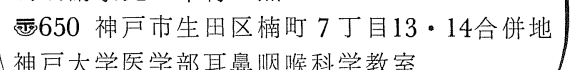

\section{耳鼻科疾患とステロイド療法}

㮰上架秀伯

一般に行なわれている合成ステロイド療法は 副腎皮質ホルモンの生理的分泌量をはるかにて える大量を投与して非特異的かつ対症的に臨床 症状の寛解を期待するものであって，あ!まで も原䛈㭧に対する根治療法ではないととは周知 のととであります。

本荗の使用にあたっては特異的代償療法（ア ヂソン病，副腎摘出後など）以外の疾患では原 則的にまず本剤の使用前に他の楽剤でコント ロールするように努め，てれが無効の時に， 特に重篤例に限って合成ステロイドを使用する
ことが望ましいといわれている。しかし，耳鼻 科疾患では合成ステロイドの使用量も少なく， 短期間使用のためまづ本剂を first choice とし て使用される疾患もある.

以下疾患別に述べることに致します。

\section{1. 突 発 難 聴}

原因は多原性と考えられ（血管障一 vasospasm, thrombosis, embolism, 出血, hypercoagulation, sludge，ウイルス，正円空破裂な ぞ）このうちでも血管障害説が広くうけいれら

Otolaryngological Diseases and Steroidtherapy.

Hidehaku Kumagami.

長崎大学医学部耳鼻咽喉科学教室 